\title{
Isolation, molecular identification, and pathological lesions of Saprolegnia spp. isolated from common carp, Cyprinus carpio in floating cages in Mosul, Iraq
}

\author{
Fawwaz Fadhil Ali1 ${ }^{(\mathbb{D})}$, Shahbaa Khalil AL-Taee ${ }^{(\mathbb{D})}$ and Zahraa Mustafa AL-Jumaa ${ }^{3}$ (D)
}

\author{
1. Department of Animal Production, Institute of Mosul, Northern Technical University, Mosul, Iraq; 2. Department of \\ Pathology and poultry diseases, College of Veterinary Medicine, Mosul, Iraq; 3. Department of Internal and Preventive \\ Medicine, College of Veterinary Medicine, Mosul, Iraq. \\ Corresponding author: Fawwaz Fadhil Ali, e-mail: fawwaz@ntu.edu.iq \\ Co-authors: SKA: shahbaa_khal@uomosul.edu.iq, ZMA: sandy285@uomosul.edu.iq \\ Received: 19-07-2020, Accepted: 05-11-2020, Published online: 24-12-2020
}

doi: www.doi.org/10.14202/vetworld.2020.2759-2764 How to cite this article: Ali FF, AL-Taee SK, AL-Jumaa ZM (2020) Isolation, molecular identification, and pathological lesions of Saprolegnia spp. isolated from common carp, Cyprinus carpio in floating cages in Mosul, Iraq, Veterinary World, 13(12): 2759-2764.

\begin{abstract}
Background and Aim: Saprolegniasis is a fungal disease that infects freshwater fish. The condition is characterized by a cotton-like appearance in the gills and body. This study aimed to isolate Saprolegnia from common carp, Cyprinus carpio, raised in a floating cage in Wana district, Mosul, Iraq.

Materials and Methods: Samples were collected from 15 infected fish and examined microbiologically, molecularly, and histopathologically. Saprolegnia DNA was extracted which was amplified using universal primers give a 540 bp DNA fragment, and gill and muscle tissue were also examined for histopathological changes.

Results: Isolated colonies of Saprolegnia were characterized by a circular, white cottony appearance with long hair. Lactophenol staining demonstrated hyphae as branched non-septate, transparent masses. The genomic DNA of isolates was consistent with Saprolegnia spp. The infected tissue samples showed variable pathology in gills. Severe hemorrhage and edema were observed in primary gill filaments with hyperplasia in epithelial cells and infusion in secondary gill filaments. Hyphae of Saprolegnia were seen between necrotic and edematous myofiber with inflammatory cells infiltration.
\end{abstract}

Conclusion: Saprolegnia can cause economic impacts through lethal infection of fish. Clinical signs of Saprolegnia infection were confirmed molecularly and microscopically, and these findings were supported by histopathological lesions in gill and muscle tissues.

Keywords: common carp, fungal isolation, histopathological changes, molecular identification, Saprolegnia.

\section{Introduction}

The eukaryotic oomycetes fungi are pathological microorganisms responsible for infections in both animals and plant infections [1]. Severe infections in fish are known as saprolegniosis disease [2,3]. Oomycetes fungi cause significant economic loses to fish production, including salmon, trout, and catfish, which are more susceptible to oomycete infection [4]. Infection is also observed in zebrafish and silver crucian carp $[5,6]$. Fish pathogens are mostly classified in the order, Saprolegniales, and eight genera infect fish, either naturally or artificially, including Calyptratheca, Leptolegnia, Achlya, Aphanomyces, Leptomitus, Pythiopsis, Thraustotheca, and Saprolegnia. Saprolegnia, Aphanomyces, and Achlya are important pathogens for aquaculture [7,8]. Infected fish display different levels of susceptibility but manifest the same symptoms [9]. Saprolegnia parasitica is responsible

Copyright: Ali, et al. Open Access. This article is distributed under the terms of the Creative Commons Attribution 4.0 International License (http://creativecommons.org/licenses/by/4.0/), which permits unrestricted use, distribution, and reproduction in any medium, provided you give appropriate credit to the original author(s) and the source, provide a link to the Creative Commons license, and indicate if changes were made. The Creative Commons Public Domain Dedication waiver (http://creativecommons.org/ publicdomain/zero/1.0/) applies to the data made available in this article, unless otherwise stated. for substantial fish mortality [10]; Saprolegnia spp. infections are closely associated with catastrophic losses in fish production in both freshwater and marine aquaculture industries [11]. Pathogenic oomycetes also infect fish eggs and cause considerable losses in fish hatcheries [12].

The oomycete infection occurs by translocation of effector proteins into infected cells; these proteins impede host defenses [13]. S. parasitica is a fish pathogen with secondary cysts characterized by clusters of long-haired hook bundles. These hooks, along with adhesive extracellular matrix and proteins (fibronectin and thrombospondin), increase the strength of cyst attachment to hosts [14], and leading to damage the host epidermis cells and consequently causes tissue damage and dehydration as a result of the release of toxic materials and body fluids [9].

No effective treatments are available for Saprolegnia infection [15]. However, some medications, such as antimicrobial peptides that enhance host immune response, have been tried [4]. Further, clotrimazole could be effective against Saprolegnia infections through pretreatment of fish eggs of freshwater-farmed fish [16]. In addition to Virkon ${ }^{\circledR} \mathrm{S}$, it has been shown to control and prevent saprolegniasis infection in common carp [17]. 
Saprolegnia causes considerable impact in local fish industries, particularly in Mosul city in North Iraq. However, limited studies are available to characterize the pathogen in this region. This study was aimed, primarily, at identification of the pathogen using microbiological, molecular, and histopathological methods. This investigation will help identify and confirm this disease's environmental distribution, thus informing development of measures to control the disease.

\section{Materials and Methods}

\section{Ethical approval}

In this study, ethical approval was not required; however, samples were collected based on the standard procedure and institutional guidelines for sample collection.

\section{Study period and location}

The infected fish were collected from different sites from floating cages in the Wana sub-district in Mosul, Iraq, from March to July 2019.

Fish

A 15 infected common carp "Cyprinus carpio" from floating cages in Wana/Mosul, Iraq, were investigated. Infected fish were examined, and samples were collected from fish that exhibited Saprolegniosis signs [18], including cotton wool-like lesions on the head, fin, and body, skin ulceration, and loss of appetite, Figure-1. These fish were placed in polyethylene bags and transported under sterile conditions to laboratories at the College of Veterinary Medicine, Mosul University, Mosul, Iraq.

Microbiological examination of the collected samples

All samples were collected and immediately transported in cold conditions. These samples were cultured on Sabouraud's dextrose agar (SDA) plates. Medium was composed of $65 \mathrm{~g}$ of SDA base with $250 \mathrm{mg}$ chloramphenicol, $26 \mathrm{mg}$ of gentamycin, $5 \mathrm{~g}$ of yeast extract, and the distilled water constituents and adjust volume $1 \mathrm{~L}$. After dissolution, $\mathrm{pH}$ was adjusted to 5.8. The inoculated plates were incubated at $20-25^{\circ} \mathrm{C}$ for $5-10$ days. Plates without positive growth were further incubated for up to 4 weeks before discarding. All positive cultures

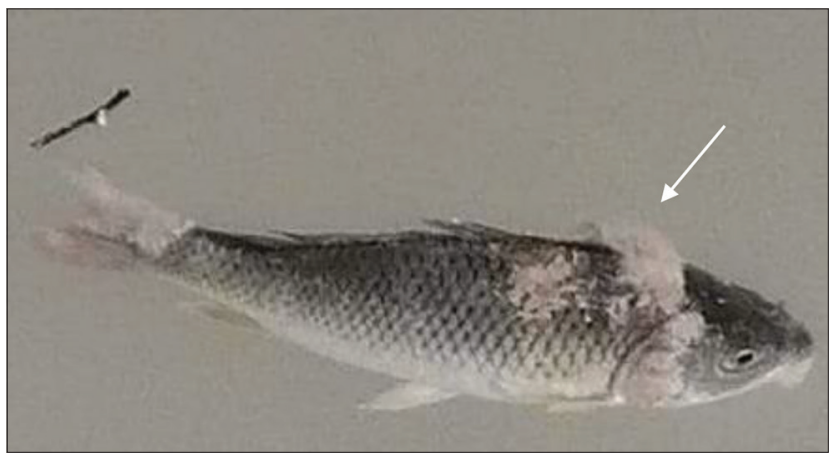

Figure-1: Cyprinus carpio infected with Saprolegnia, the diseased fish exhibit the characteristic manifestation of water fungus infection. The arrow is pointed to cottony wool-like lesions on fish skin. were subcultured using SDA plates to obtain pure axenic single colonies. These plates were incubated at $20-25^{\circ} \mathrm{C}$ for $3-5$ days. For microscopic examination, slides were prepared from each colony using a tape method. Transparent tape was lightly pressed onto growing colonies. The tape was fixed over a clean slide with a drop of lactophenol cotton blue stain. Stained slides were observed under a microscope at $50 \times$ and $200 \times$ to identify this fungus, using a fungal identification key [19]. Shape and diameter of hyphae and spores from isolated fungi were measured. All purified cultures were examined for macro- and micromorphological characteristics. Gross morphological examination recorded the rate of the fungal growth, texture, changes in color during growth, the final color of surface, and reverse sides of the colonies.

\section{DNA analysis}

The DNA of Saprolegnia was extracted directly from infected fish tissues according to the manufacturer instructions (gSYNCTM Geneaid Extraction Kit). Briefly, collected samples were prepared and DNA extracted following kit manual instructions. All extracted DNAs were stored at $-20^{\circ} \mathrm{C}$ until analyzed. Molecular identification of Saprolegnia used the internal transcribed spacer (ITS) region. Sequencing used universal primers ITS1 (TCCGTAGGTGAACCTGCGG) and ITS4 (TCCTCCGCTTATTGATATGC). Two pairs of primers (forward and reverse) were synthesized by BIONEER Co. (Korea) for targeting the fungus. Polymerase chain reaction (PCR) reaction used a $25 \mu \mathrm{L}$ reaction volume and described in Table- 1 . The amplification program is specified in Table-2.

All PCR products were analyzed using 2\% agarose gel electrophoresis (Biometra, Germany), with $0.2 \mu \mathrm{L}$ ethidium bromide in TBE buffer. DNA bands were visualized with a UV transilluminator.

\section{Histological examination}

Different infected tissues included gill affected by sloughing and necrotic appearance and muscle with ulceration. The selected tissues were separated and fixed in 10\% neutral buffered formalin for 48-72 h. Samples were then embedded in paraffin, and $5 \mu \mathrm{m}$ tissue sections were cut using a microtome. The tissue sections were then fixed on slides and stained with hematoxylin and eosin stain [20-22].

Table-1: Final polymerase chain reaction volume composition (total volume of $25 \mu \mathrm{L}$ ).

\begin{tabular}{lc}
\hline Content & Amount $(\boldsymbol{\mu L})$ \\
\hline Forward primer $(10 \mathrm{picomol} / \mu \mathrm{L})$ & 1 \\
Reverse primer $(10 \mathrm{picomol} / \mu \mathrm{L})$ & 1 \\
Template DNA $250 \mathrm{ng} / \mu \mathrm{L}$ & 5 \\
$\mathrm{DDW}$ & 6.5 \\
$\mathrm{MgCl}_{2}$ & 1.5 \\
Mstermix $2.5 \times$ & 10 \\
Total volume & 25 \\
\hline
\end{tabular}


Table-2: Polymerase chain reaction setting program of amplification.

\begin{tabular}{lccl}
\hline Number of cycles & Adjusted temperature $\left({ }^{\circ} \mathbf{C}\right)$ & Time & Discretion \\
\hline 1 & 95 & $5 \mathrm{~min}$ & Initial DNA denaturation \\
30 & 95 & $20 \mathrm{~s}$ & DNA denaturation \\
& 57 & $30 \mathrm{~s}$ & Primer annealing \\
1 & 72 & $30 \mathrm{~s}$ & Primer extension \\
1 & 72 & $5 \mathrm{~min}$ & Final extension \\
\hline
\end{tabular}

\section{Results}

\section{Saprolegniosis disease symptoms and colonies morphology}

The infected common carp showed loss of appetite and a white to gray cotton-like growth cover on fish skin, fins, and gills (Figure-1). Cultured fungus on SDA plates showed characteristic morphology and proper growth of Saprolegnia. Colonies start to be observed within 4 days of incubation. These colonies are circular with a cottony appearance, white in color, with long hairs (Figure-2). This evidential characteristic of diseased common carp and colony morphology indicated Saprolegnia infection.

\section{Microscopic examination}

The microscopic examination revealed branched non-septate, transparent masses varying in length and width. Hyphae of Saprolegnia isolates stained with lactophenol cotton blue stain (Figure-3).

\section{PCR analysis}

The extracted DNA was amplified to identify Saprolegnia spp. molecularly using universal primers. The amplification PCR products showed the target identified 540 bp DNA fragment (Figure-4), which indicates the fungal Saprolegnia. All 50 samples were analyzed and present positive results.

\section{Histological examination}

Gills

The infected gills showed sloughing of primary gill filaments, severe hemorrhage with edema, and infiltration of inflammatory cells (Figure-5). This infected tissue showed other histopathological changes, such as hyperplasia of epithelial cells, infusion of secondary gill filaments and partial occlusion interlamellar space (Figure-6). Besides, the hypertrophy of mucus, chloride, and pillar cells combined with hemorrhage, edema, and lifting epithelial cells (Figure-7).

\section{Muscles}

Microscopic examination of infected muscle exhibited myofibril degeneration and necrosis with edema. Penetrating fungal hyphae into the muscle layer was also observed (Figure-8) in addition to moderate infiltration of inflammatory cells with severe fungal hyphae penetration into muscle fibers (Figure-9).

\section{Discussion}

The fish industry in Iraq has grown considerably [23]. About 1,074,000 hectares of water

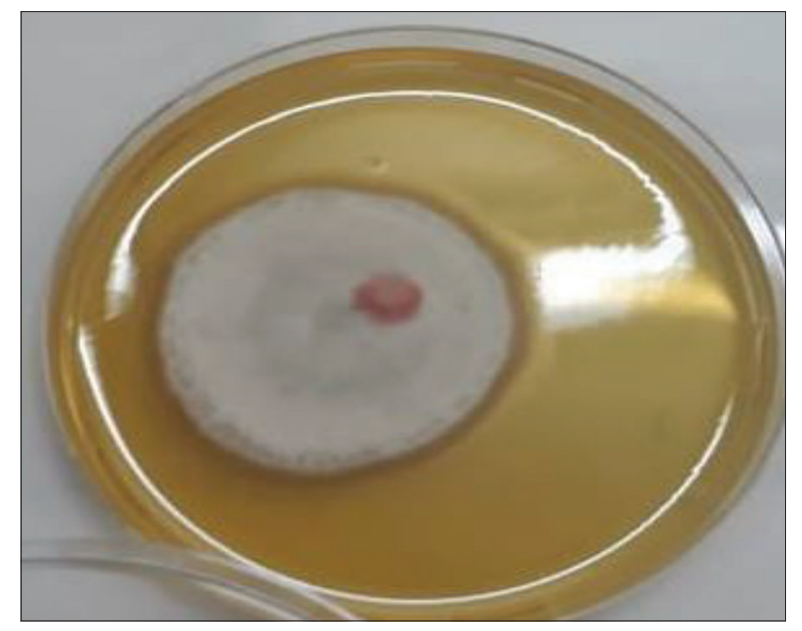

Figure-2: Macroscopic morphology of isolated Saprolegnia spp., the macroscopic appetence, and characteristics of isolated fugues, the positive Saprolegnia spp. colony (Sabouraud's dextrose agar) after 14 days of incubation at $25^{\circ} \mathrm{C}$. The colony appeared as a circular cottony with long hairs and white.

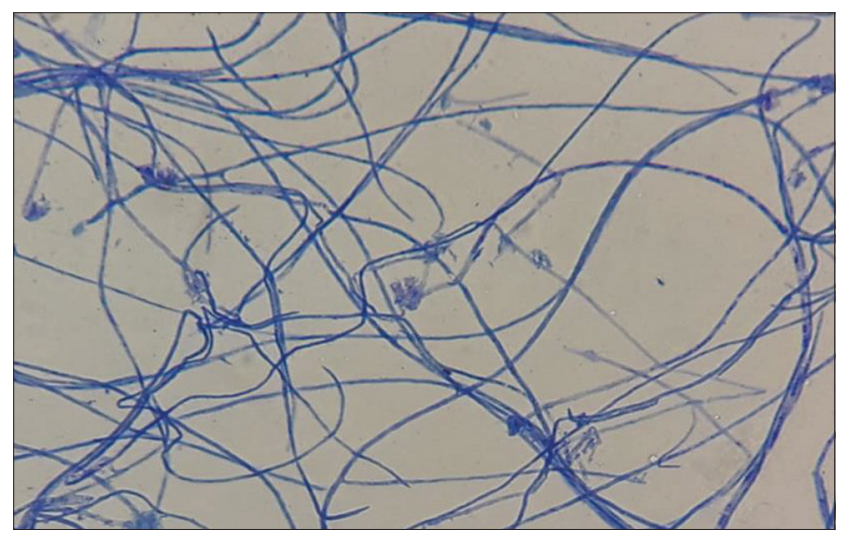

Figure-3: The microscopic characterization of isolated fungus. The microscopic inspection of the isolated fungus showed the branched non-septate hyphae of Saprolegnia isolate, together with masses (different in length and width), transparent and has a cell membrane stained with lactophenol cotton blue stain. These images were obtained using a $40 \times$ objective lens.

resources, including revisers, lakes, reservoirs, and other resources, are involved in fish production [24]. The spread of fish disease is increasing challenges and economic losses, particularly for increasing fish mortality $[25,26]$.

This research identifies the oomycete fungus, Saprolegnia, in isolates from common carp C. carpio from floating cages in Wana/Mosul, Iraq. Classical and molecular-based analyses were applied, supported 


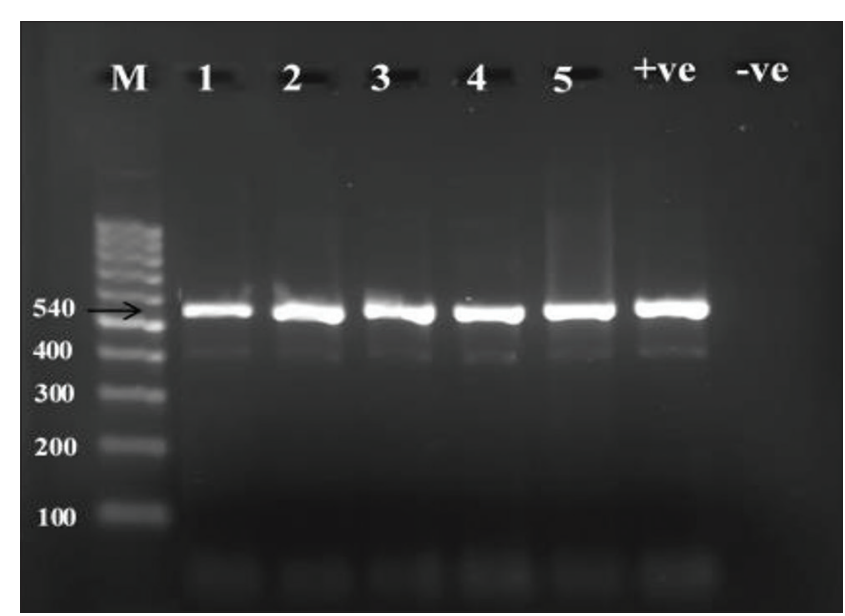

Figure-4: The polymerase chain reaction (PCR) amplification products of TSI on $2 \%$ agarose gel. The TSI was amplified from extracted DNA using the condition described in materials and methods. Four microliters of PCR amplification product were mixed with $1 \mu \mathrm{L}$ of loading buffer for DNA electrophoresis, and then, the mixture was loaded for each well of $2 \%$ agarose gel. The DNA size was indicated using the DNA ladder. M: Marker (100-1000 bp). 1-5: Sample numbers that showed positive at $540 \mathrm{bp} .+\mathrm{ve}$ : Positive control, positive and -ve: Negative control.

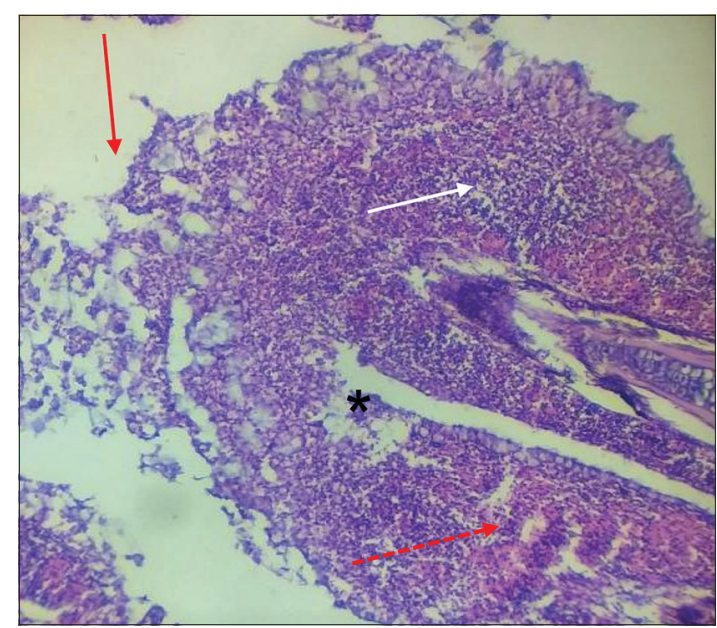

Figure-5: Gills of Cyprinus carpio infected with Saprolegnia exhibit sloughing of a pix of primary gill filament (red row), severe hemorrhage (red dot row) with edema (black star), and infiltration of inflammatory cells (white row). H\&E.

by histopathology. Samples were collected from fish infected with Saprolegnia spp. which were identified based on symptoms, physiological characteristics, molecular analysis, and histopathological changes.

The oomycetes fungus, Saprolegnia, is pervasive in freshwater, and it is the significant cause of freshwater fungal infection of fish and eggs [27] and is the main cause of saprolegniasis [28]. This disease causes high fish mortality, particularly in winter [29]. Infected $C$. carpioshow characteristic cotton-like growth on skin, gills, and fins (Figure-1). Saprolegnia infects and penetrates the fish epidermis. The infection begins on fins or heads and spreads to other parts of fish bodies [30,31]. The fungus was isolated using SDA medium. Different media have been used to separate this fungus, including MEA,

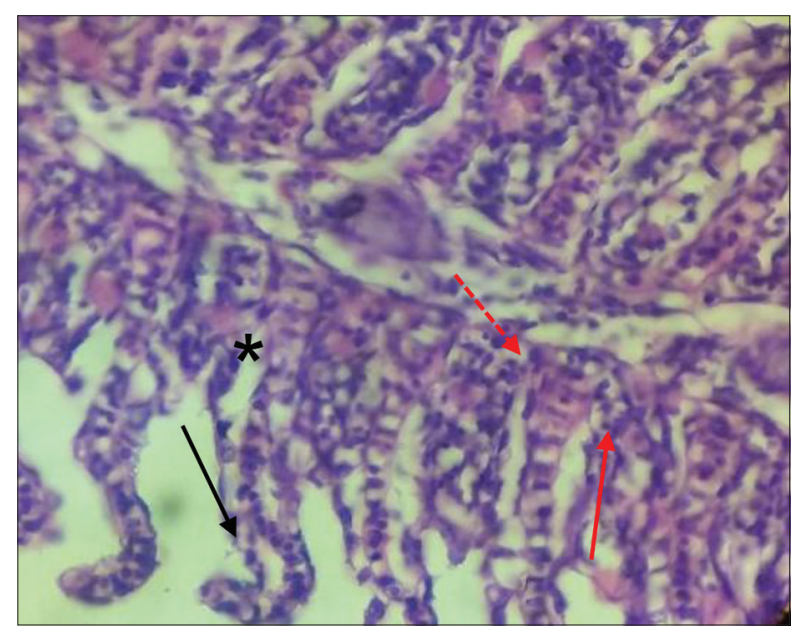

Figure-6: Gills of Cyprinus carpio infected with Saprolegnia exhibit partial occlusion of interlamellar spaces (red row), hyperplasia of epithelial gill filament (red dot row) with edema (black star), and infusion of secondary gill filament (black row). H\&E, $1 \times 40$.

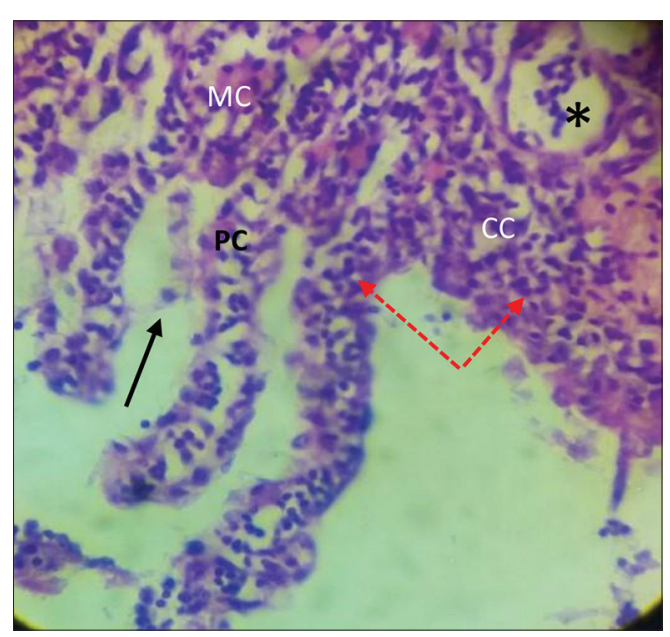

Figure-7: Gills of Cyprinus carpio infected with Saprolegnia exhibit hypertrophy of mucus cells, chloride cells, and pillar cells with edema (black star) and lifting epithelial cells (black row), hemorrhage (red row) with infiltration of inflammatory cells (red dot row) $\mathrm{H} \& \mathrm{E}, 1 \times 40$.

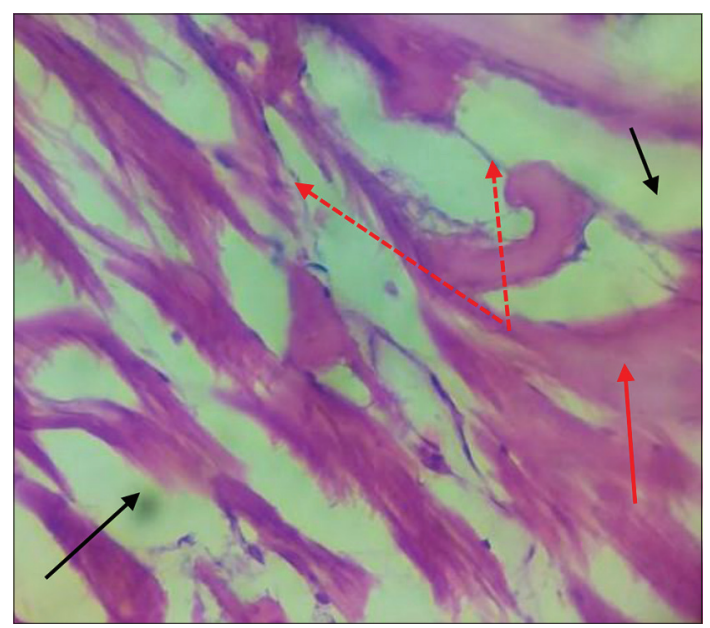

Figure-8: Muscles of Cyprinus carpio infected with Saprolegnia exhibit necrosis of muscle fiber (red row), edema (black row) with penetrating fungal hyphae were observed in muscle fiber (red dot row) $\mathrm{H} \& \mathrm{E}, 1 \times 40$. 


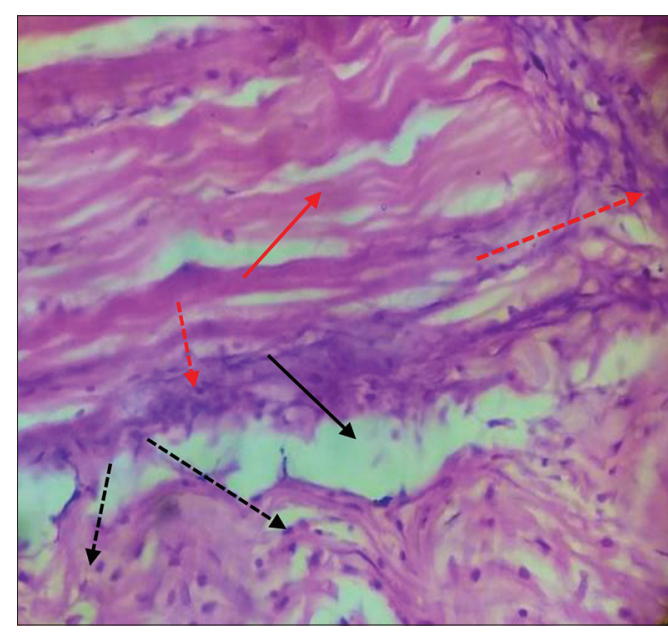

Figure-9: Muscles of Cyprinus carpio infected with Saprolegnia exhibit necrosis of muscle fiber (red row), edema (black row) with penetrating severe fungal hyphae were observed in muscle fiber (red dot row) moderate infiltration of inflammatory cells (black dot row) H\&E, $1 \times 40$.

PDA, and SDA, with varying growth rates and areal mycelium formation [32]. Culture characteristics supported by PCR effectively confirmed Saprolegnia infection [33]; non-coding ITS regions ITS1 of rDNA are widely accepted genetic markers because of their relatively high sequence variability and the availability of primers for amplification of fungal sequences. These ITS regions are located between two coding regions, the $18 \mathrm{~S}$ and $28 \mathrm{~S}$ genes. Molecular analysis of these regions was adopted to confirm Saprolegnia isolates [34,35].

Histopathological changes in gills of infected fishes showed sloughing of primary gill filaments, combined with edema and severe hemorrhage with signs of inflammation. These histopathological changes are often reported [36-38]. Examination of infected muscle tissue showed degeneration and necrosis of myofibrils. Such pathology is also reported previous investigation of Saprolegnia infection $[17,39,40]$. Lesions caused by oomycetes disease include loss of integument integrity, degeneration of infected muscles, and edema. Deep penetration into muscle fiber is observed in severe infections with focal cellular necrosis [39]. Intracellular epidermal edema and epidermal sloughing enhance basement membrane penetration by the fungal hyphae [41] Penetration of fungal hyphae to the muscle layer was also observed. Such damage is also reported previously in Saprolegnia infection [17,39,41,42].

\section{Conclusion}

We conclude that Saprolegnia spp. was isolated and confirmed molecularly in isolates from infected common carp in floating cages in Wana district, Mosul, Iraq. The histopathological lesions in infected fish gills and muscles support this evidence. Further investigation is needed to define the environmental distribution of infected fungal-like pathogens and other related mycotic pathogens in fish farms in Iraq, thus facilitating the design of mycotic infection control program to reduce or eliminate economic losses.

\section{Authors' Contributions}

SKA and ZMA accomplished sample collection and experimental design; FFA analyzed, interpreted the data and drafted the manuscript, all authors involved in manuscript reading and editing. All authors read and approved the final manuscript.

\section{Acknowledgments}

The authors are grateful to the Department of Pathology and Poultry Diseases and the Department of Internal and Preventive Medicine, College of Veterinary Medicine, the University of Mosul for all kinds of support and facilities to complete this study. The authors did not receive any funds for this study.

\section{Competing Interests}

The authors declare that they have no competing interests.

\section{Publisher's Note}

Veterinary World remains neutral with regard to jurisdictional claims in published institutional affiliation.

\section{References}

1. Wuensch, A., Trusch, F., Iberahim, N.A. and van West. (2018) Galleria mellonella as an experimental in vivo host model for the fish-pathogenic oomycete Saprolegnia parasitica. Fungal Biol., 122(2-3): 182-189.

2. van West, P., de Bruijn, I., Minor, K.L., Phillips, A.J., Robertson, E.J., Wawra, S., Bain, J., Anderson, V.L. and Secombes, C.J. (2010) The putative RxLR effector protein SpHtp1 from the fish pathogenic oomycete Saprolegnia parasitica is translocated into fish cells. FEMS Microbiol. Lett., 310(2): 127-137.

3. Rzeszutek, E., Diaz-Moreno, S.M. and Bulone, V. (2019) Identification and characterization of the chitin synthase genes from the fish pathogen Saprolegnia parasitica. Front. Microbiol., 10: 2873.

4. de Bruijn, I., Belmonte, R., Anderson, V.L., Saraiva, M., Wang, T., van West, P. and Secombes, C.J. (2012) Immune gene expression in trout cell lines infected with the fish pathogenic oomycete Saprolegnia parasitica. Dev. Comp. Immunol., 38(1): 44-54.

5. Ke, X., Wang, J., Gu, Z., Li, M. and Gong, X. (2009) Saprolegnia brachydanis, a new oomycete isolated from zebrafish. Mycopathologia, 167(2): 107-113.

6. Ke, X.L., Wang, J.G., Gu, Z.M., Li, M. and Gong, X.N. (2009) Morphological and molecular phylogenetic analysis of two Saprolegnia sp. (Oomycetes) isolated from silver crucian carp and zebrafish. Mycol. Res., 113(5): 637-644.

7. Hatai, K. and Hoshiai, G.I. (1993) Characteristics of two Saprolegnia species isolated from coho salmon with saprolegniosis. J. Aquat. Anim. Health, 5(2): 115-118.

8. Bly, J.E., Lawson, L.A., Abdel-Aziz, E.S. and Clem, L.W. (1994) Channel catfish, Ictalurus punctatus, immunity to Saprolegnia sp. J. Appl. Aquac., 3(1-2): 35-50.

9. Tiffney, W.N. (1939) The host range of Saprolegnia parasitica. Mycologia, 31(3): 310-321.

10. Rocchi, S., Tisserant, M., Valot, B., Laboissière, A., Frossard, V. and Reboux, G. (2017) Quantification of Saprolegnia parasitica in river water using real-time quantitative PCR: From massive fish mortality to tap drinking water. Int. J. Environ. Health Res., 27(1): 1-10. 
11. Tedesco, P., Beraldo, P., Massimo, M., Fioravanti, M.L., Volpatti, D., Dirks, R. and Galuppi, R. (2020) Comparative therapeutic effects of natural compounds against Saprolegnia spp. (Oomycota) and Amyloodinium ocellatum (Dinophyceae). Front. Vet. Sci., 7: 83.

12. Earle, G. and Hintz, W. (2014) New approaches for controlling Saprolegnia parasitica, the causal agent of a devastating fish disease. Trop. Life Sci. Res., 25(2): 101-109.

13. Wawra, S., Bain, J., Durward, E., de Bruijn, I., Minor, K.L., Matena, A., Löbach, L., Whisson, S.C., Bayer, P., Porter, A.J., Birch, P.R.J., Secombes, C.J. and van West, P. (2012) Host-targeting protein 1 (SpHtp1) from the oomycete Saprolegnia parasitica translocates specifically into fish cells in a tyrosine-O-sulphate-dependent manner. Proc. Natl. Acad. Sci. U. S. A., 109(6): 2096-2101.

14. Rezinciuc, S., Sandoval-Sierra, J.V., Ruiz-León, Y., van West, P. and Diéguez-Uribeondo, J. (2018) Specialized attachment structure of the fish pathogenic oomycete Saprolegnia parasitica. PLoS One, 13(1): e0190361.

15. Belmonte, R., Sandoval-Sierra, J.V., Ruiz-León, Y.V. and Diéguez-Uribeondo, J. (2014) Role of pathogen-derived cell wall carbohydrates and prostaglandin E2 in immune response and suppression of fish immunity by the oomycete Saprolegnia parasitica. Infect. Immun., 82(11): 4518-4529.

16. Warrilow, A.G., Hull, C.M., Rolley, N.J., Parker, J.E., Nes, W.D., Smith, S.N., Kelly, D.E. and Kelly, S.L. (2014) Clotrimazole as a potent agent for treating the oomycete fish pathogen Saprolegnia parasitica through inhibition of sterol 14alpha-demethylase (CYP51). Appl. Environ. Microbiol., 80(19): 6154-6166.

17. Ashour, A.A., Mustafa, S. A. and Yassein, S.N. (2017) Histopathological Studies on Common Carp Cyprinus carpio L. Infected with Saprolegnia sp. and Treated with Virkon ${ }^{\circledR}$. Vol. 6. MRVSA, Baghdad. p19-30.

18. Peyghan, R., Rahnama, R., Dezfuly, Z.T. and Shokoohmand, M. (2019) Achlya infection in an oscar (Astronotus ocellatus) with typical symptoms of saprolegniosis. Vet. Res. Forum., 10(1): 89-92.

19. Ellis, D., Davis, S., Alexiou, H., Handke, R. and Bartley, R. (2007) Descriptions of Medical Fungi. Nexus Print Solutions, Adelaide, South Australia, Australia.

20. Roberts, R.J. (2001) Fish Pathology. W.B. Saunders, Edinburgh.

21. Abdel-Latif, H.M.R., Abdel-Tawwab, M., Khafaga, A.F. and Dawood, M.A.O. (2020) Dietary Origanum essential oil improved antioxidative status, immune-related genes, and resistance of common carp (Cyprinus carpio L.) to Aeromonas hydrophila infection. Fish Shellfish Immunol., 104: 1-7.

22. Abdel-Latif, H.M.R., Abdel-Tawwab, M., Khafaga, A.F. and Dawood, M.A.O. (2020) Dietary oregano essential oil improved the growth performance via enhancing the intestinal morphometry and hepato-renal functions of common carp (Cyprinus carpio L.) fingerlings. Aquaculture, 526: 735432 .

23. Al-Salem, A.F.B. (2013) Technical and economical evaluation of fish cage culture projects in Babylon Province. In: Al-Musaib Technical College. Foundation of Technical Education, Babil, Iraq. p181.

24. Mhaisen, F.T. (1993) A review on the parasites and disease in fish ponds and farms of Iraq. Iraqi J. Vet. Sci., 6(2): 20-28.

25. Gjedrem, T. (2015) Disease resistant fish and shellfish are within reach: A review. J. Mar. Sci. Eng., 3(1): 146-153.

26. Abdel-Latif, H.M.R., Dawood, M.A.O.,
Menanteau-Ledouble, S. and El-Matbouli, M. (2020) The nature and consequences of co-infections in tilapia: A review. J. Fish Dis., 43(6): 651-664.

27. Pelczar, M.J., Chan, E.C.S. and Krieg, N.R. (2008) Microbiology. $5^{\text {th }}$ ed. Tata Mc Graw Hill Publishing Company Ltd., New Delhi, India.

28. Li, C. and Tian, Q. (2011) Choice of chemicals to prevent or control saprolegniasis in songpu mirror carp eggs. Chin. J. Fish., 24(4): 37-39.

29. Das, S.K., Murmu, K., Das, A., Shakuntala, I., Das, R.K., Ngachan, S.V. and Majhi, S.K. (2012) Studies on the identification and control of pathogen Saprolegnia in selected Indian major carp fingerlings at mid-hill altitude. J. Environ. Biol., 33(3): 545-549.

30. Neish, G.A. (1977) Observations on saprolegniasis of adult sockeye salmon, Oncorhynchus nerka (Walbaum). J. Fish Biol., 10(5): 513-522.

31. Willoughby, L.G. and Roberts, R.J. (1992) Towards strategic use of fungicides against Saprolegnia parasitica in salmonid fish hatcheries. J. Fish Dis., 15(1): 1-13.

32. Mazurkiewicz-Zapałowicz, K., Twarużek, M., Grzonka, J. and Kurzydłowski, K.J. (2015) The effect of magnetic field on in vitro development of fungus-like organisms Saprolegnia parasitica on selected microbiological media. Electron. J. Pol. Agric. Univ., 18(2): 2.

33. Molina, F.I., Jong, S.C. and Ma, G. (1995) Molecular characterization and identification of Saprolegnia by restriction analysis of genes coding for ribosomal RNA. Antonie Leeuwenhoek, 68(1): 65-74.

34. de la Bastide, P.Y., Leung, W.L. and Hintz, W.E. (2015) Species composition of the genus Saprolegnia in finfish aquaculture environments, as determined by nucleotide sequence analysis of the nuclear rDNA ITS regions. Fungal Biol., 119(1): 27-43.

35. Sandoval-Sierra, J.V., Martín, M.P. and DiéguezUribeondo, J. (2014) Species identification in the genus Saprolegnia (Oomycetes): Defining DNA-based molecular operational taxonomic units. Fungal Biol., 118(7): 559-578.

36. Chauhan, R. and Bhat, M.H. (2014) Histopathological manifestations in commercially important fish, Clarias batrachus (L.) found infected with Saprolegnia diclina. Indo Am. J. Pharm. Res., 2(168): 1168-1172.

37. Songe, M.M., Willems, A., Wiik-Nielsen, J., Thoen, E., Evensen, O., van West, P. and Skaar, I. (2016) Saprolegnia diclina III A and $S$. parasitica employ different infection strategies when colonizing eggs of Atlantic salmon, Salmo salar L. J. Fish Dis., 39(3): 343-352.

38. Refai, M.K., Mohamed, A. and Amany, M. (2010) The assessment of myotic settlement of freshwater fishes in Egypt. J. Am. Sci., 6: 595-602.

39. Copland, J.W. and Willoughby, L.G. (1982) The pathology of Saprolegnia infections of Anguilla anguilla L. elvers. J. Fish Dis., 5(5): 421-428.

40. Hussein, M.M.A. and Hatai, K. (2002) Pathogenicity of Saprolegnia species associated with outbreaks of salmonid saprolegniosis in Japan. Fish. Sci., 68(5): 1067-1072.

41. Bootsma, R. (1973) Infections with Saprolegnia in pike culture (Esox lucius L.). Aquaculture, 2(1): 385-394.

42. Shin, S., Kulatunga, D.C.M., Dananjaya, S.H.S., Nikapitiya, C., Lee, J., De Zoysa, M. (2017) Saprolegnia parasitica isolated from rainbow trout in Korea: Characterization, anti-saprolegnia activity and host-pathogen interaction in zebrafish disease model. Mycobiology, 45(4): 297-311. 